OSAS

\title{
Modification of growth, immunologic and feeding parameters in children with OSAS after adenotonsillectomy
}

\author{
Modificazioni dei parametri di crescita, immunologici e alimentari in bambini \\ con OSAS dopo adenotonsillectomia
}

\author{
M. CASSANO ${ }^{1}$, G. RUSSO ${ }^{1}$, C. GRANIERI ${ }^{1}$, D. CIAVARELLA² \\ ${ }^{1}$ Department of Clinical and Experimental Medicine, Section of Otorhinolaryngology, University of Foggia, Italy; \\ 2 Department of Clinical and Experimental Medicine, Dental School, University of Foggia, Italy
}

\begin{abstract}
SUMMARY
Obstructive sleep apnoea syndrome can cause growth delay in children. Adeno-tonsillectomy can resolve the syndrome in most cases. The aim of our study is to examine modifications in clinical and laboratory growth and immunological parameters and food intake changes in OSAS children after surgery. Twenty-eight children with severe OSAS associated with adeno-tonsillar hypertrophy were submitted to paediatric evaluation to calculate auxologic parameters (weight, height, BMI and standard deviation scores), a blood draw to evaluate growth (GH; IGF-1) and immunological parameters (IgG; IgA; IgM) and a dietitian evaluation to calculate caloric intake before and after 3 months following adeno-tonsillectomy. Mean height and weight values in the study group were slightly inferior to same-age children mean according to the percentile values. After surgery, both height and BMI increased significantly at 3-months follow-up: mean height increased $2.93 \mathrm{~cm}(\mathrm{p}=0.0001)$; BMI values greatly increased by $0.72 \mathrm{~kg} / \mathrm{m}^{2}(\mathrm{p}=0.009)$. Standard deviation scores increased significantly for height $(\mathrm{p}=0.03)$, weight $(\mathrm{p}=0.001)$ and BMI $(\mathrm{p}=0.001)$. These values significantly increased, despite almost unchanged caloric intake between the pre- and post-surgery period ( $90 \pm 24 \mathrm{vs} 91 \pm 27 \mathrm{kcal} /$ $\mathrm{kg}$ /day; $\mathrm{p}>0.05$ ). In all children, age-related $\mathrm{GH}$ values were normal and did not show any significant increase, while IGF-1 values significantly increased during the study period $(\mathrm{p}=0.01)$. Regarding immunological parameters, only IgA levels decreased after surgery and maintained a value that was higher than normal (>70 mg/dL). In conclusion, children affected by adenotonsillar hypertrophy and OSAS do not show significant growth delay, but they do experience a slowdown in growth rate. After adeno-tonsillectomy, the speed of growth soon increases, as weight and growth increase notwithstanding an unchanged food intake. Moreover, surgery does not cause reduction in the efficiency of the immune system.
\end{abstract}

KEY WORDS: Obstructive sleep apnoea syndrome $\bullet$ GH $\bullet$ IGF-1 $\bullet$ Adeno-tonsillectomy $\bullet$ Growing delay $\bullet$ Adenotonsillar hypertrophy

\section{RIASSUNTO}

La Sindrome delle apnee ostruttive del sonno può essere causa di ritardo nell'accrescimento in età pediatrica. Nella maggior parte dei casi l'intervento di adenotonsillectomia è in grado di risolvere la Sindrome apnoica. Obiettivo dello studio è verificare le modificazioni della crescita staturo-ponderale e dei parametri ormonali di accrescimento e immunologici nonché dietetici in bambini affetti da OSAS dopo intervento di adenotonsillectomia. Sono stati pertanto esaminati ventotto bambini affetti da OSAS severa e ipertrofia adenotonsillare. Tali bambini sono stati sottoposti a valutazione pediatrica per studiare i parametri auxologici (peso, altezza, BMI e standard deviation score), ad un prelievo ematico per studiare i parametri ormonali di crescita (GH e IGF-1) e i parametri immunologici (IgG, IgM e IgA) ed infine ad una valutazione dietologica per calcolare l'introito calorico. Le stesse valutazioni sono state ripetute dopo tre mesi dall'intervento di adenotonsillectomia. Le altezze e i pesi medi del gruppo di studio nella fase iniziale risultavano leggermente inferiori rispetto alle medie dei percentili della stessa età. Al controllo a tre mesi dall'intervento invece sia il BMI che l'altezza mostravano un aumento significativo: l'altezza mostrava un incremento di 2,93 cm ( $p=0,0001)$; il BMI era aumentato di $0,72 \mathrm{~kg} / \mathrm{m}^{2}(p=0,009)$. Lo standard deviation score $(S D S)$ risultava aumentato sia per il parametro altezza $(p=0,03)$, che per il peso $(p=0,001)$ che per il BMI ( $p=0,001)$. Tutti questi incrementi si verificavano in assenza di una reale variazione di introito calorico tra il periodo pre e post-operatorio $(90 \pm 24$ vs $91 \pm 27 \mathrm{kcal} / \mathrm{kg} /$ die; $p>0,05)$. In tutti i bambini esaminati inoltre non sono emersi significativi incrementi dei valori del GH che risultavano normali anche prima dell'intervento mentre $i$ valori dell' IGF-1 aumentavano significativamente durante il periodo di studio $(p=0,01)$. Per quanto riguarda invece i parametri immunologici, solo le IgA mostravano una riduzione peraltro non significativa nel post-operatorio, mantenendosi comunque su valori più alti della norma $(>70 \mathrm{mg} / \mathrm{dL}$ ). Dal lavoro quindi emerge che i bambini affetti da OSAS e ipertrofia adenotonsillare non presentano un significativo ritardo di accrescimento ma sicuramente hanno un rallentamento nella crescita. Dopo l'intervento di adenotonsillectomia la velocità di crescita aumenta, in quanto vi è un incremento del peso e dell'altezza, nonostante non cambi l'introito calorico. Inoltre l'intervento di adenotonsillectomia non causa una reale riduzione di efficienza del sistema immunitario.

PAROLE CHIAVE: Sindrome delle apnee ostruttive del sonno $\bullet$ GH $\bullet I G F-1 \bullet$ Adenotonsillectomia $\bullet$ Ritardo di crescita $\bullet$ Ipertrofia adenotonsillare

Acta Otorhinolaryngol Ital 2018;38:124-130 


\section{Introduction}

Obstructive sleep apnoea hypopnea syndrome (OSHAS) is characterised by recurring episodes of complete or partial upper airway collapse during sleep, resulting in snoring and apnoeas or hypopnoeas. Whereas apnoea is a complete cessation of airflow, hypopnea is characterised by a $70 \%$ reduction of airflow for $\geq 10 \mathrm{sec}$ or any reduction in airflow that is associated with either an arousal from sleep or $\mathrm{a} \geq 3 \%$ arterial oxygen desaturation. In children, hypopnoeas are more common than apnoeas and absence of airflow is uncommon. OSHAS affects up to $2.5 \%$ of children and adolescents with snoring as its primary symptom, affecting up to $27 \%$ of individuals in this group.

In children, the reduction of airflow (RA) is often related to adeno-tonsillar hypertrophy (ATH) and is considered one of the most important factors in growth alteration ${ }^{1}$.

Thus, it has been related to reduction of growth hormone (GH) secretion in these patients. GH is a peptide hormone synthesised and secreted by the pituitary gland and its primary function is to promote growth mostly through inducing synthesis of insulin-like growth factor type 1 (IGF-1 or somatomedin C). IGF-1 stimulates protein synthesis, above all in growth cartilages and muscles. Moreover, it promotes insulin-like effects on carbohydrate and lipid homeostasis $^{2}$. It circulates bound to at least 6 different binding proteins that regulate its bioavailability. From a clinical point of view, the most important is IGFBP-3, whose levels are regulated by both GH and IGF-1. Furthermore, IGF-1 levels, through an unclear mechanism, are modulated by food intake and greatly decrease in all malnutrition conditions ${ }^{3}$. GH secretion is pulsatile and is stimulated by GHRH and Ghrelin, while it is inhibited by SRIH, following alternating stages. Variable and episodic peaks, associated with consumption of proteic meals or physical activity, superimpose the fundamental pulsatility, while constant peaks occur during sleep stages 3 and 4, 1-4 hours after falling asleep ${ }^{4}$. Thus, sleep fragmentation associates with an abnormal GH secretion ${ }^{5}$. Indeed, GH secretion is suppressed in non-treated OSAS patients ${ }^{6}$. However, even if it is ascertained that adenotonsillectomy surgery resolves the symptoms along with growth problems in OSAS children ${ }^{7-10}$, its effect on the patients' immune system is not clear. While most authors report no significant reductions of serum levels of immunoglobulins ${ }^{11}$, others have reported that such changes are able to influence immune status ${ }^{12-13}$. The purpose of the present study is to investigate changes in clinical and laboratory growth (GH and IGF-1), immunological ( $\operatorname{IgA}, \operatorname{IgG}$ and $\operatorname{IgM}$ ) parameters and food intake in children with OSAS after adeno-tonsillar surgery.

\section{Materials and methods}

The study was performed between March and October 2012, at the Otorhinolaryngology Department of the University of Foggia, evaluating children affected by adenotonsillar hypertrophy with obstructive symptoms, apnoea and nocturnal respiratory problems. The patients underwent diagnostic exams included in the paediatric sleep respiratory problems protocol.

The protocol consisted in the following diagnostic procedures:

- Clinical history: symptoms were evaluated through questions made by the examiner regarding snoring, episodes of sleep apnoea (reported by parents), daily sleepiness, daily hyperactivity, concomitant lower airways pathologies, immune system or endocrine diseases.

- ENT general evaluation: facial morphologic evaluation (to exclude cranio-facial malformations) and oral cavity examination (evaluating teeth, uvulo-palatal morphology, tonsils and tongue base). Uvulo-palatal morphology was classified according to the Finkelstein classification, and tonsil hypertrophy using the tonsil grading score ${ }^{14}$.

- Anterior rhinoscopy and fibre endoscopy: to evaluate the presence of turbinate enlargement, adenoid hypertrophy, classified by Cassano score ${ }^{15}$ and associated sino-nasal pathologies (septal deviation, sinusitis, nasal polyposis, etc.).

- Nocturnal cardiorespiratory monitoring with Somnoscreen polysomnography (SOMNOmedics GmbH, Randersacker, Germany) for evaluation of the apnoea/hypopnoea index (AHI), baseline $\mathrm{SpO}_{2}$, lowest $\mathrm{SpO}_{2}$, number of desaturations $<90 \%$, snoring and body positions.

The presence of severe OSAS (AHI > 10 at cardio-respiratory monitoring) associated with adeno-tonsillar hypertrophy was the main criterion for inclusion. Exclusion criteria were the presence of malformations of the upper airway, craniofacial anomalies, asthma, perennial allergies and chromosomal abnormality of trisomy 21 (Down's syndrome). Patients who met inclusion and exclusion criteria were enrolled in the study group and underwent the following exams:

- Paediatric evaluation to calculate auxologic parameters (weight, height, BMI). Weight was approximated to the closest half kilogram and was measured with a medical precision scale, while height was evaluated using the Harpenden stadiometer. Body mass index $\left(\mathrm{BMI} ; \mathrm{kg} / \mathrm{m}^{2}\right)$ was considered as a relative weight index. In prepubertal children, height and weight increases are expected, and thus the real weight, height and BMI increment was evaluated through standard deviation scores (SDS, z-scores) calculated according to standard national tables. 
- Blood draw to evaluate the following growth and immunological parameters:

- $\mathrm{GH}$

- IGF-1;

- IgA;

- IgG;

- IgM.

For GH and IGF-1 dosage, a solid-phase, two-site chemiluminescent immunometric assay was used. A single polystyrene sphere is delivered into a special reaction test-tube that is used as a container for incubation, washing and signal development processes. Antibody anti-reagents were present on the spheres. An alkaline phosphatase (detection antibody) with two antibodies was used. After overnight incubation at room temperature, the reaction was terminated and the reaction mixture was separated. After incubation, the serum samples were aspirated and the spheres were washed twice with $7 \mathrm{ml}$ of distilled water. The spheres were then evaluated for luminescence and the fluorescence intensity of the solution was measured with a fluorimeter. The amount of emitted light is directly proportional to the amount of linked alkaline phosphatase.

- Food diary, written by the dietitian to calculate caloric intake.

These assessments were repeated at 3 months from adeno-tonsillectomy surgery to evaluate changes in weight, growth, immunological status and associated haematological parameters. The Review Board of the Department of Otolaryngology approved the study protocol.

Parents of children in the study group gave informed consent to study participation and provided precise information about daytime and night-time symptoms.

The work was carried out in accordance with the code of Ethics of the Declaration of Helsinki for experiments involving humans.

\section{Statistical analysis}

Correlation between physical exam results and AHI were statistically evaluated by applying Pearson's correlation, Wilcoxon and logistic regression tests. To evaluate the rate of growth, body composition and IGF-1 levels during presurgical period and after three months a Friedman analysis was used. To evaluate the difference in values, a Wilcoxon signed-ranch test was used.

Regarding all tests, a $\mathrm{p}<0.05$ was considered significant. Statistical analyses were performed using SOFA Statistics 1.2.2 version software. Data treatment and graphs were obtained using LibreOffice 3.5.4 version productivity software (The Document Foundation) and LATEX. All software was launched in Linux Debian 6.0 "Squeeze".

\section{Results}

Twenty-eight children (15 boys and 13 girls) with an age between 48 and 108 months (mean $73.40 \pm 18.47$ months) fit the inclusion and exclusion criteria, and were therefore enrolled in the study.

Eighteen patients had a grade 4 adenoid hypertrophy (64.3\%), while 10 had grade $3(35.7 \%)$. According to the Tonsil Score, 20 children $(71.4 \%)$ showed grade 4 , while 8 children $(28.6 \%)$ had grade 3.

Polysomnographic results classified all children as affected by severe OSHAS, with an AHI mean value of $16.2 / \mathrm{h}$, mean basal saturation of $86 \%$ and $<90 \%$ desaturation of a mean of 8 . Study group mean height before surgery was $116.81 \mathrm{~cm}$, weight was $22.17 \mathrm{~kg}$ and BMI was $16.22 \mathrm{~kg} /$ $\mathrm{m}^{2}$. Preoperative height and weight values in OSAS children were lower compared to mean percentile values of same-age children. The food diary showed a pre-surgical caloric intake of $90 \pm 24 \mathrm{kcal} / \mathrm{kg}$ per day.

During the post-surgery period, both height and BMI increased significantly after 3-months follow-up: mean height increased by $2.93 \mathrm{~cm}$, from $116.81 \mathrm{~cm}$ to $119.74 \mathrm{~cm}$

Table I. Anthropometric parameters and standard deviation scores (SDS) at pre-operative and 3-month follow-up.

\begin{tabular}{llcc} 
Anthropometric measurements & & Values & SDS (Z-scores) \\
Height $(\mathrm{cm})$ & Pre-operative & $116.81 \pm 11.41$ & $0.24 \pm 0.97$ \\
& Follow-up & $119.74 \pm 10.62$ & $0.26 \pm 1.01$ \\
& & $p=0.03$ & $p=0.03$ \\
Weight $(\mathrm{kg})$ & Pre-operative & $22.17 \pm 5.43$ & $0.23 \pm 1.32$ \\
& Follow-up & $24.73 \pm 6.17$ & $0.42 \pm 1.29$ \\
& & $p=0.0001$ & $p=0.001$ \\
BMl $\left(\mathrm{kg} / \mathrm{m}^{2}\right)$ & Pre-operative & $16.22 \pm 2.54$ & $0.52 \pm 1.90$ \\
& Follow-up & $16.94 \pm 1.98$ & $0.61 \pm 1.42$ \\
& & $p=0.009$ & $p=0.001$ \\
\hline
\end{tabular}


$(\mathrm{p}=0.0001) ; \mathrm{BMI}$ values greatly increased by $0.72 \mathrm{~kg} / \mathrm{m}^{2}$ ( $\mathrm{p}=0.009$ ) from 16.22 to $16.94 \mathrm{~kg} / \mathrm{m}^{2}$ during the postoperative period. The standard deviation scores increased significantly for height $(\mathrm{p}=0.03)$, weight $(\mathrm{p}=0.001)$ and BMI $(\mathrm{p}=0.001)$ (Table I).

Thus, those values greatly increased despite the almost unchanged caloric intake between pre- and post-surgery period $(90 \pm 24$ vs $91 \pm 27 \mathrm{kcal} / \mathrm{kg} /$ day; $\mathrm{p}>0.05)$.

In all children, age-related GH values were normal and did not show a significant increase (mean: $0.5 \mathrm{ng} / \mathrm{ml}$ ), while IGF-1 values greatly increased during the study period (from 162.4 to $284.6 \mathrm{ng} / \mathrm{ml} ; \mathrm{p}=0.01$ ) (Fig. 1).

Immunoglobulin levels were measured in all patients. IgG dosage results showed an initial mean value of $1005.87 \mathrm{mg} / \mathrm{dL}$, with a statistically significant difference between males (mean: $967.24 \mathrm{mg} / \mathrm{dL}$ ) and females (mean: $1061.35 \mathrm{mg} / \mathrm{dL})(\mathrm{p}=0.03)$. After 3-months follow-up, mean values were $956.49 \mathrm{mg} / \mathrm{dL}$.

IgA levels decreased during post-surgery period $(106.64 \mathrm{mg} / \mathrm{dL})$; however, they remained in a higher-thannormal range ( $>70 \mathrm{mg} / \mathrm{dL})$. In this case, no statistically significant sex-related differences were found.

Pre-surgery IgM mean value was $102.42 \mathrm{mg} / \mathrm{dL}$; after 3 months, this value was almost the same $(101.87 \mathrm{mg} / \mathrm{dL})$. Sexrelated differences were found; specifically, males showed a greater reduction than females, but none of the differences were statistically significant. The values were always higher than normal (> 50 mg/dL) and substantial difference between pre- and post-surgery was never found (Fig. 2).

\section{Discussion}

Growth is divided in many phases as described to Bjork. The modifications of the general body end in the sexual maturation phase. Growth is related to many factors such as alimentation, hormones, physical activity and psychoaffective disorders. All of these factors have negative effects on GH secretion ${ }^{4}$.

In the recent years, there is increasing interest in respiratory disorders in children with growth alterations. Respiratory stimulus is one of the most important stimuli in both cranial and body growth. Much research has shown that adenotonsillar hypertrophy may be associated with a slowing or stopping of growth during paediatric age 91016 .

Growth deficit, which often affects OSAS children, is correlated with sleep disorders and GH secretion during growth. Many generic parameters are used to evaluate growth in children: weight and growth modifications, caloric intake, body mass index and height increase. Recently, other parameters GH secretion and IGF-1 have also been used to evaluate growth.

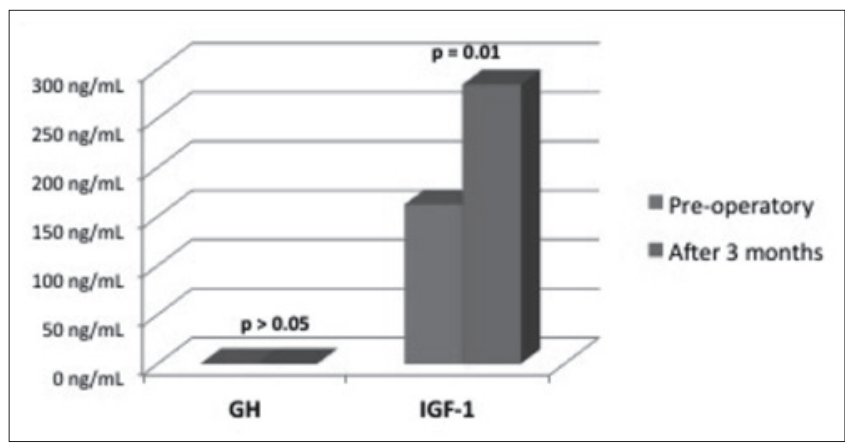

Fig. 1. Pre-operative and 3-month follow-up of GH and IGF-1 values (Wilcoxon's Test).

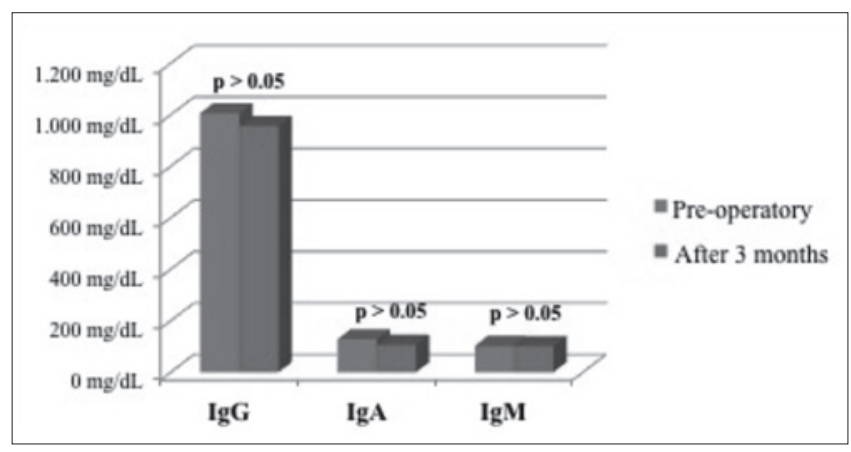

Fig. 2. Pre-operative and 3-months follow-up of immunoglobulins (Wilcoxon's Test).

In older children, Singer and Saenger evaluated a relationship between slow wave sleep phases and GH release. In order to study the negative influence exerted by OSAS on growth because of reduced GH secretion, the authors measured pre- and post-surgery GH levels in an achondroplastic child who had underwent tracheotomy for a severe respiratory sleep disorder. Before surgery, GH levels were very low, coincidently with apnoea episodes and absence of slow wave sleep; surgery normalised both sleep parameters and GH sleep-related release. The study clearly showed that OSAS prevents GH production, leading to negative effects on growth ${ }^{6}$.

In the present paper, there was no evident delay in growth. The height of study children's was only slightly less than same-age children, just below the 3rd percentile.

Another way to express auxologic values is the Standard Deviation Score (SDS) adjusted according to age and $\mathrm{sex}^{4}$, and height increase measured by SDS can be a sign of a height increase.

Stradling also demonstrated a significant height-related SDS increase at six months after adeno-tonsillectomy surgery compared to a healthy control group. The study reported growth rates of $7.5 \mathrm{~cm} /$ year in the control group, compared 
to $9.7 \mathrm{~cm} /$ year in treated children at 6 months from surgery. These results thus indicate a potential growth speed acceleration at 3-6 months after surgery ${ }^{7}$.

Contrasting results were reported in another study by Bar et al. who found a non-significant height increase (SDS) compared to healthy patients at 18 months after surgery ${ }^{9}$.

Weight is considered an important wellness parameter in children ${ }^{16}$. Many studies have shown that weight increased in children undergoing adeno-tonsillectomy ${ }^{7-10}$. Similarly, in the present paper, we found a significant weight increase at three months from surgery. During the pre-operative period, weight was approximately equal to that of same-age children; at the end of the follow-up period, weight increase was higher in treated patients, despite the unchanged caloric intake.

Marcus analysed caloric intake related to caloric expenditure and anthropometric measures in 14 prepubertal OSAS children before and after adeno-tonsillectomy. That study showed that nocturnal mean caloric expenditure decreased while weight-related SDS increased, despite the absence of significant caloric intake differences between the two periods. Even if the "Sleep Energy Expenditure" (SEE) decreased during sleep, a major reduction was observed during the REM stage. Moreover, children with higher SEE values had the lowest $\mathrm{Z}$ score values $(r=-0.62 ; \mathrm{p}<0.05)$. Thus, the authors concluded that SEE reduction and weight gain improved thanks to surgery, believing that the basic mechanism could have been caused by increased energy expenditure due to increased respiratory work during sleep in OSAS children ${ }^{17}$.

BMI is a widely used method to define the relationship between weight and height. In this study, we observed a substantial BMI increase at the end of the observation period. During the preoperative period, higher than normal BMI values can be explained by the similar weight and lower growth of OSAS children compared to healthy children ${ }^{18}$.

This can be demonstrated by the weight/height index. BMI index and weight/height index substantially increase in treated children as shown in previous studies ${ }^{19}$. BMI increase can be caused by fat mass increase compared to lean mass increase.

Serum IGF-1 values show minimal growth-related alterations during the prepubertal period ${ }^{18}$. All examined children herein stayed in the prepubertal stage during the study period. Growth increase, especially weight gain after surgery, was followed by a significant serum IGF-1 concentration increase. This is in accordance with previous literature reports ${ }^{7-917}$.

IGF-1 is in close correlation with physiologic variations in $\mathrm{GH}$ secretion and is generally known as the most important mediator in GH promoting-growth activities ${ }^{3}$, reflecting GH daily mean values ${ }^{2}$. It was also demonstrated that IG-
FBP-3 levels, the main GH-dependent IGF-1 transport protein, significantly relate with nocturnal GH secretion, even if this correlation is not as strong as that applied to IGF- $1^{2}$. In the present paper, we noted substantial increases in serum IGF levels, which reflect same-age normal population values, as shown in other studies ${ }^{919}$.

Growth alteration in OSAS patients can correlate with abnormal nocturnal GH secretion caused by modifications in sleep patterns ${ }^{4}$. In nutritional deficits such as protein malnutrition and nervous anorexia, IGF-1 and IGFBP-3 concentrations are noticeably decreased ${ }^{20}$. The markedly lower IGF-1 levels found in patients compared to mean values in healthy people can be due to lower GH levels.

The increases in growth rate and IGF-1 concentration seen during follow-up are important indicators of an increase in plasma concentrations of $\mathrm{GH}$.

After surgery, clinical conditions appeared noticeably improved, as both parents and children themselves reported. Nocturnal awakenings, diurnal sleepiness or hyperactivity as well as edginess and focus capacity, are positively affected by therapy, allowing a better quality of life and a greater opportunity for the child to grow up in a healthy condition. However, removal of adeno-tonsillar lymphatic structures can influence the patient's immune status. In fact, the role of the Waldayer ring lymphoid tissue in the production of immunoglobulin and lymphocytes is well known.

In the literature, several papers report a reduction in serum levels of $\operatorname{IgG}$, IgM and secreting IgA after tonsillectomy ${ }^{21-24}$. During the postoperative period, these values more or less quickly stabilised. According to other authors, Ig levels barely change ${ }^{25}$. Moreover, there are in vitro studies that show increases in Ig production after tonsillectomy, implying a stimulating effect on immunity ${ }^{26}$.

During the 1980s and 1990s, some studies suggested that serum and salivary Ig levels might be higher than expected by clinical signs ${ }^{13}$ or increased risk of respiratory postoperative infections ${ }^{12}$, although other studies have not confirmed this ${ }^{27}$; this dispute is still ongoing.

In the present study, we determined pre- and post-operative Ig values in children affected by adeno-tonsilar hypertrophy, without other concurrent pathologies, and examined if changes in these levels could influence the respiratory tract immune system. First of all, mean levels were never lower than normal values. Moreover, infectious complications were not related to this during follow-up.

These complications can be pyogenic and recurrent infections in $\operatorname{IgG}$ deficit cases; in IgA reduction cases, increased risk of respiratory infections, otitis, allergies, autoimmune diseases and neoplasia can occur; finally, in cases with reduced IgM, there can be meningitis, septicaemia, recurrent otitis and respiratory tract infections ${ }^{11}$. 
According to another study by Amoros Sebastia et al., who analysed data at one month and 4 months from surgery, $\operatorname{IgG}$ serum levels underwent a major reduction, showing a decrease after one month and partial restoration after 4 months. The most noticeable difference reported by our study, compared to literature data, is that this reduction was more prominent and recovery was less in patients who underwent only adenotomy, compared to those who had the adenoids and tonsils removed $(\mathrm{p}<0.1)$. These data are contrary to the theory according which removal of the palatal tonsils, the main IgG producer, should give rise to such results ${ }^{11}$.

Thus, we conclude that tonsils do not appear very important in influencing serum IgG levels. Moreover, IgA serum levels experience a slight reduction during 4-months follow-up, and IgM serum levels do not show any significant changes. Hence, adeno-tonsillectomy surgery implies that IgG and IgA serum levels do decrease, but never below normal range, while IgM serum levels do not change after surgery, supporting the meager influence exerted by pharyngeal lymphoid tissue on Ig secretion ${ }^{28}$.

\section{Conclusions}

Children affected by adeno-tonsillar hypertrophy and OSAS do not show significant growth delay, but do present a slowdown in growth rate. After adeno-tonsillectomy surgery, growth increased, as shown by increases in weight gain and growth after the three-months post-operative period, probably due to weight gain. These results suggest that GH levels and outcomes are greater after surgery and produce growth acceleration. Considering that OSAS complications are various, adeno-tonsillectomy should always be considered because of the possible evolution towards irreversible and sometimes cardiovascular pathologies. Surgery does not cause substantial reduction in the immune system and can be useful to reach the growth-weight optimum in OSAS children.

\section{References}

1 Bower CM, Gungor A. Pediatric obstructive sleep apnea syndrome. Otolaryngol Clin North 2000;33:49-75.

2 Blum WF, Albertsson-Wikland K, Rosberg S, et al. Serum levels of insulin-like growth factor 1 (Igf-1) and Igf binding protein 3 reflect spontaneous growth hormone secretion. $\mathrm{J}$ Clin Endocrinol Metab 1993;76:1610-6.

3 Furlanetto RW. Insulin-like growth factor measurements in the evaluation of growth hormone secretion. Hor Res Paediatr 1990;33:25-30.

4 Clayton P, Gill MS. Normal growth and its endocrine control. In: Brook CDG, Hindmarsh PC, Jacobs HS, eds. Clinical Pediatric Endocrinology. Fourth Edition. London, UK: Blackwell Science; 2001. p. 95-114.
5 Cooper BG, White JE, Ashworth LA, et al. Hormonal and metabolic profiles in subjects with obstructive sleep apnea syndrome and the acute effects of nasal continuous positive airway pressure (C-pap) treatment. Sleep 1995;18:172-9.

6 Singer LP, Saenger P. Complications of pediatric obstructive sleep apnea. Otolaryngol Clin North Am 1990;23:665-76.

7 Stradling JR, Tomas G, Warley ARH, et al. Effect of adenotonsillectomy on nocturnal hypoxaemia, sleep disturbance, and symptoms in snoring children. Lancet 1990;335:249-53.

8 Williams EF, Woo P, Miller R, et al. The effects of adenotonsillectomy on growth in young children. Otolaryngol Head Neck Surg 1991;104:509-16.

9 Bar A, Tarasiuk A, Segev Y, et al. The effect of adenotonsillectomy on serum insulin-like growth factor and growth in children with obstructive sleep apnea syndrome. J Pediatr 1999;135:76-80.

10 Harding SM. Complications and consequences of obstructive sleep apnea. Curr Opin Pulm Med 2000;6:485-9.

11 Redondo Ventura F, Guerrero Gilabert D, Reina Garcia P, et al. Niveles sericos de inmunoglobulinas en pacientes adenoamigdalectomizados. Un misterio sin resolver. Acta Otorrinolaring Esp 2000;51:403-6.

12 Cantani A, Bellioni P, Salvinelli F, et al. Serum immunoglobulins and secretory IgA defciency in tonsillectomized children. Ann Allergy 1986;57:413-6.

13 Friday Jr GA, Paradise JL, Rabin BS, et al. Serum immunoglobulin changes in relation to tonsil and adenoid surgery. Ann Allergy 1992;69:225-30.

14 Finkelstein Y, Talmi YP, Nachmani A, et al. On the variability of velopharyngeal valve anatomy and function: a combined peroral and nasendoscopic study. Plast Reconstr Surg 1992;89:631-9.

15 Cassano P, Gelardi M, Cassano M, et al. Adenoid tissue rhinopharyngeal obstruction grading based on fiberendoscopic findings: a novel approach to therapeutic management. Int J Ped Otorhinolaryngol 2003;67:1303-9.

16 Chan J, Edman JC, Koltai PJ. Obstructive sleep apnea in children. American Family Phyisician 2004;69:1147-60.

17 Marcus CL, Carroll JL, Koerner CB, et al. Determinants of growth in children with the obstructive sleep apnea syndrome. J Pediatr 1994;125:556-62.

18 Juul A, Bang P, Hertel NT, et al. Serum insulin-like growth factor-i in 1030 healthy children, adolescents, and adults:relation to age, sex, stage of puberty, testicular size, and body mass index. J Clin Endocrinol Metab 1994;78:744-52.

19 Nieminen P, Lopponen T, Tolonen U, et al. Growth and biochemical markers of growth in children with snoring and obstructive sleep apnea. Pediatrics 2002;109:e55.

20 Palacio AC, Perez-Bravo F, Santos JL, et al. Leptin levels and Igf-binding proteins in malnourished children: effect of weight gain. Nutrition 2002;18:17-9.

21 Childers NK, Powell WD, Tong G, et al. Human salivary immunoglobulin and antigen specific antibody activity after tonsillectomy. Oral Microbiol Immunol 2001;16:265-9.

22 Jung KY, Lim HH, Choi G, et al. Age-related changes of IgA immunocytes and serum and salivary IgA after tonsillectomy. Acta Otolaryngol Suppl 1996;523:115-9. 
23 Kirstila V, Tenovuo J, Ruuskanen O, et al. Longitudinal analysis of human salivary immunoglobulins, nonimmune antimicrobial agents, and microfora afer tonsillectomy. Clin Immunol Immunopathol 1996;80:110-5.

24 Zielnik-Jurkiewicz B, Jurkiewicz D. Implication of immunological abnormalities after adenotonsillotomy. Int J Ped Otorhinolaryngol 2002;64:127-32.

25 Paulussen C, Claes J, Claes G, et al. Adenoids and tonsils, indications for surgery and immunological consequences of surgery. Acta Otorhinolaryngol Belg 2000;54:403-8.

26 Sainz M, Gutierrez F, Moreno PM, et al. Changes in immu- nologic response in tonsillectomized children. Immunosuppression in recurrent tonsillitis. Clin Otolaryngol Allied Sci 2007; 17:376-9.

27 Bock A, Popp W, Herkner KR. Tonsillectomy and the immune system: a long-term follow up comparison between tonsillectomized and non-tonsillectomized children. Eur Arch Otorhinolaryngol 1994;251:423-7.

28 Amoros Sebastia LI, Ferrer Ramirez MJ, Lopez Molla $\mathrm{C}$, et al. Changes in immunoglobulin levels following adenoidectomy and tonsillectomy. Acta Otorrinolaringol Esp 2004;55:404-8.

Received: August 13, 2016- Accepted: March 11, 2017

Address for correspondence: Michele Cassano, via Guerrieri 2,

71100 Foggia, Italy. E-mail: michele.cassano@unifg.it. 